\title{
EFFECTIVENESS OF ANNEALING TREATMENT AND POLYMER BLENDS ON I-V CHARACTERISTSICS OF POLYMER SOLAR CELL
}

\author{
Erlyta Septa Rosa*) and Shobih \\ Pusat Penelitian Elektronika dan Telekomunikasi-Lembaga Ilmu Pengetahuan Indonesia (PPET-LIPI) \\ Kampus LIPI, Jl. Sangkuriang Bandung 40135 \\ Telp./Fax. : 62-22-2504660/2504659 \\ ${ }^{*}$ Corresponding author: erlytasr@gmail.com
}

\begin{abstract}
This research reports on a fabrication of polymer solar cells based on blends of two widely used polymeric semiconductors i.e. poly(2-methoxy-5-(3,7-dimethyloctyloxy)-para phenylene vinylene) (MDMO-PPV) and the soluble fullerene C60 derivative [6,6 phenyl C61-butyric acid methyl ester] (PCBM). The devices were fabricated on an indium tin oxide (ITO) coated glass substrate. After cleaned and dried, a poly(3,4-ethylenedioxythiophene):poly(styrenesulfonate) (PEDOT:PSS) in $\mathrm{H}_{2} \mathrm{O}$ was spin coated onto the freshly prepared substrate and then dried in a vacuum oven at $120^{\circ} \mathrm{C}$ for 60 minutes. A blend of MDMO-PPV and PCBM in chlorobenzene was spin coated on the top and dried in a nitrogen ambient at room temperature for 24 hours. The devices were transferred to a sputtering system where an aluminum was coated. Some of the devices then were annealed in a vacuum oven at $60{ }^{\circ} \mathrm{C}$ for 60 minutes. Finally, the devices were encapsulated by placing a sealant between the back of the devices and glass slides and then cured in a vacuum oven at temperature $100{ }^{\circ} \mathrm{C}$ for 10 minutes. For characterization, the devices were illuminated with a xenon lamp at the intensity of $27 \mathrm{~mW} / \mathrm{cm}^{2}$ and the temperature at approximately $25^{\circ} \mathrm{C}$. The influence of the annealing treatment and polymer blends on the photovoltaic performance of the devices was also discussed here. The best performance was obtained from the device with a blend ratio of 1:1 MDMO-PPV/PCBM without annealing treatment. The typical power efficiency was $0.01 \%$ with open circuit voltage of $0.347 \mathrm{~V}$, short circuit current of $0.064 \mathrm{~mA}$, and maximum power of $0.006 \mathrm{~mW}$.
\end{abstract}

Keywords: annealing; polymeric semiconductor; polymer solar cells

\begin{abstract}
Abstrak
EFEKTIFITAS PERLAKUAN ANNEALING DAN PENCAMPURAN POLIMER TERHADAP SIFAT I-V POLIMER SEL SURYA. Tulisan ini melaporkan hasil penelitian mengenai pembuatan sel surya polimer berbasis campuran polimer semikonduktor [poli (2-metoksi-5-(3,7-dimetiloktiloksi)para fenilenvinilen)] atau MDMO-PPV dengan turunan fuleren C60 yakni [6,6 fenil C61-asam butirat metil ester] atau PCBM. Divais sel surya polimer dibuat di atas substrat kaca slide yang telah dilapisi dengan material transparan konduktif indium tin oxide (ITO). Larutan poly(3,4ethylenedioxythiophene):poly(styrenesulfonate) (PEDOT:PSS) dilapiskan di atas permukaan ITO dengan cara spin coating, kemudian substrat dikeringkan dalam oven vakum pada temperatur $120^{\circ} \mathrm{C}$ selama 60 menit. Selanjutnya juga dengan cara spin coating, campuran polimer MDMO-PPV dan PCBM dalam pelarut chlorobenzene dilapiskan di atas permukaan PEDOT:PSS, dan dikeringkan dalam lingkungan nitrogen selama 24 jam. Kemudian dilapisi dengan aluminium menggunakan teknik sputtering. Beberapa dari divais tersebut kemudian diannealing dalam oven vakum pada temperatur $60^{\circ} \mathrm{C}$ selama 60 menit. Sebagai tahap akhir, dilakukan kapsulasi dengan menempatkan sealant termoplastik di antara bagian belakang divais dan kaca slide, dan dipanaskan dalam oven vakum pada temperatur $100^{\circ} \mathrm{C}$ selama 10 menit. Karakterisasi sel surya polimer dilakukan dengan menyinari devais menggunakan cahaya lampu xenon pada intensitas $27 \mathrm{~mW} / \mathrm{cm}^{2}$ dan temperatur sekitar $25^{\circ} \mathrm{C}$. Pengaruh perlakuan annealing dan rasio campuran polimer terhadap kinerja sel surya polimer juga dibahas dalam tulisan ini. Sel surya polimer yang mempunyai kinerja terbaik dihasilkan dari divais sel surya dengan rasio campuran MDMO-PPV/PCBM 1:1 tanpa perlakuan annealing.
\end{abstract}


Efisiensi daya yang didapat adalah 0,01\% dengan tegangan sirkit terbuka 0,347 V; arus hubungan singkat 0,064 mA; dan daya maksimum $0.006 \mathrm{~mW}$.

Kata kunci: annealing; polimer semikonduktor; sel surya polimer

\section{INTRODUCTION}

The discovery of photo induced charge transfer in composites of conjugated polymer and fullerene initiated a strong research effort toward exploitation of this process as an efficient charge-generation step in organic photovoltaic devices with the aim of fabricating low-cost solar cells (Veenstra et al., 2004). The large exiton-binding energy in a polymeric matrix result in strongly localized electron hole-pairs upon light absorption, giving rise to the small excitondiffusion length and inefficient exciton dissociation (Chen et al., 2009). Photovoltaic cells made from single organic semiconductors therefore have tiny power conversion efficiencies and low incidentphoton-to-current or external quantum efficiencies (EQE) (Brabec, 2004). A solution was only found in 1995, when several groups independently showed that the EQE could be enhanced by several orders of magnitude upon blending two materials. This blend was a relative preference for positive and negative charges resulting in a device architecture often referred to as the bulk heterojunction. The difference in electron affinities creates a driving force at the interface between the two materials that is strong enough to split photo generated exciton. By blending materials on a nanostructured scale (about $10 \mathrm{~nm}$ ), the interface is distributed throughout the device (Brabec, 2004).

The concept of a bulk heterojunction is shown in Figure 1 together with a band structure of a typical device displaying the relevant energetic levels (highest occupied molecular orbital (HOMO) of the electron donor, lowest unoccupied molecular orbital (LUMO) of the electron acceptor. The chemical structure of some materials used in organic solar cells is presented in Figure 2 (Mozer and Sariciftci, 2006). The charge carriers are generated by photo induced electron transfer from the LUMO of the electron donor (conjugated polymer) to the LUMO of the electron acceptor (PCBM). For efficient charge generation, an exciton photo generated anywhere in the blend has to reach an acceptor site within its lifetime; therefore, the magnitude of the maximum allowed phase separation is determined by the parameter called exciton diffusion length. For efficient photovoltaic devices, however, the created charge carriers need to be transported to the corresponding electrodes within their lifetime, which will be a strong function of charge carrier mobility of the materials. The ability of transporting both charges in a blend of donor and acceptor materials will be also a strong function of morphology, i.e. creating interpenetrating, bicontinuous network of both materials. As a last step, charge carriers are extracted from the device through two selective contacts. A transparent indium tin oxide (ITO) coated glass matching the HOMO level of the conjugated polymer (hole contact) is used on the illumination side, and evaporated thin $(80-100 \mathrm{~nm})$ lithium fluoride/aluminum metal contact matching the LUMO of PCBM (electron contact) is used on the other side. In the state-of-the-art devices, a thin (100 $\mathrm{nm}$ ) hole-injection layer, a highly doped PEDOT-PPS film is used, which also serves to smoothen the surface of the ITO and to increase device stability. The maximum open circuit voltage of a MDMO-PPV: PCBM device is $\sim 0.8 \mathrm{~V}$ at room temperature, which corresponds to the energy level difference between the LUMO of PCBM, and the HOMO of MDMO-PPV. Moreover, it was observed that the open-circuit voltage was only a very weak function of the work function of the cathode material used, but strongly depends on the LUMO of the electron acceptor used (Mozer and Sariciftci, 2006).

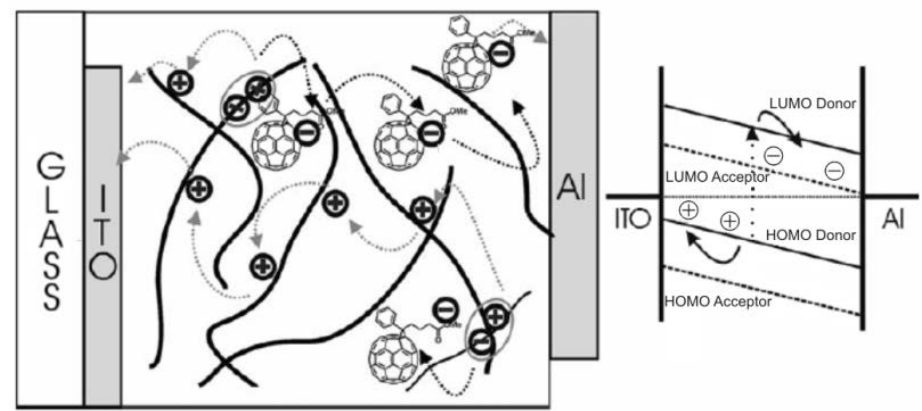

Figure 1. Schematic illustration of a bulk heterojunction based on the interpenetrating network of a conjugated polymer and PCBM. Charge carriers generated by photo-induced electron transfer are moving towards the corresponding electrode. The electronic levels relevant to the device operation are also displayed (Mozer and Sariciftci, 2006) 


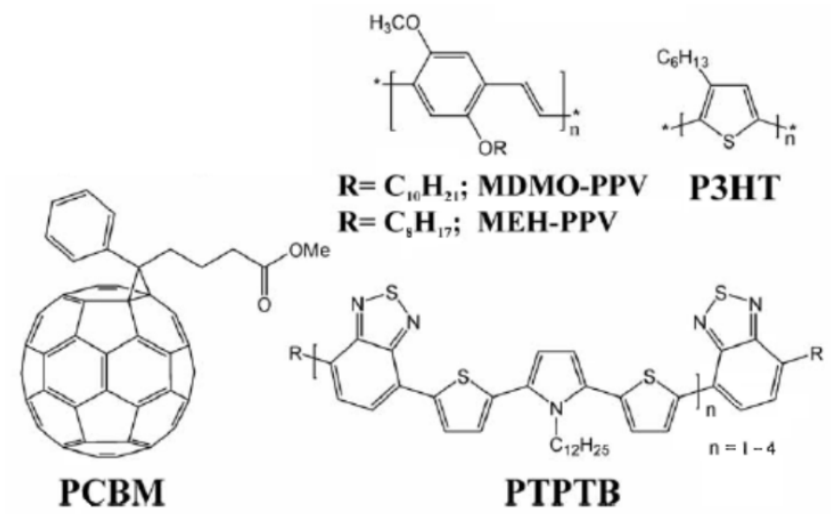

Figure 2. Chemical structures of materials used in plastic solar cells: MDMO-PPV poly[2-methoxy-5-(3,7dimethyloctyloxy)-phenylene vinylene], P3HT (poly(3-hexylthiophene-2,5-diyl), PCBM 1-(3-

methoxycarbonyl)propyl-1-phenyl-(6,6)-C61, and PTPTB (poly- $N$-dodecyl-2,5,-bis(2'-thienyl)pyrrole,2,1,3benzothiadiazole (Mozer and Sariciftci, 2006)

The main issues of improving solar cell efficiency are (i) optimization of the nanomorphology, i.e. to understand and control parameters influencing the phase separation in the photoactive blend, (ii) determination and improvement of the charge carrier mobility and (iii) improving the spectral sensitivity, for e.g. by using low band gap conjugated polymers (Mozer and Sariciftci, 2006). This research reports on a fabrication of polymer solar cells based on blends of two widely used polymeric semiconductors with [poly(2-methoxy-5-(3,7dimethyloctyloxy)-para phenylene vinylene)] (MDMO-PPV) and the soluble fullerene C60 derivative [6,6 phenyl C61-butyric acid methyl ester] (PCBM). These polymers act as an active layer for bulk heterojunction photovoltaic devices. The influences of the annealing treatment and polymer blends on the photovoltaic performance of the devices is demonstrated here.

\section{MATERIALS AND METHODS}

The structure of the bulk heterojunction solar cell is shown in Figure 3. The substrates used were ITO covered glass-slides (Aldrich 703192) in $25 \mathrm{~mm}$ $\times 25 \mathrm{~mm} \times 1.1 \mathrm{~mm}$ dimension with a ITO thickness of $120 \mathrm{~nm}$ and a sheet resistance of 8-12 $\Omega /$ square.

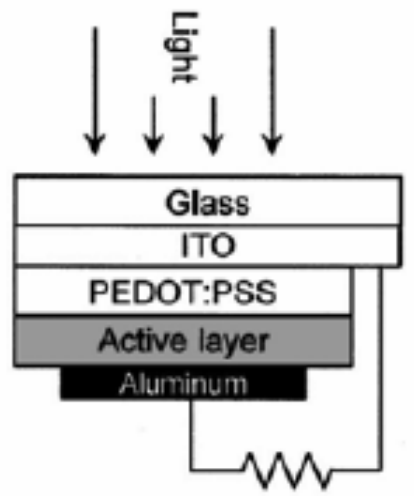

Figure 3. Device structure of the bulk heterojunction solar cell connected to an external load
The substrates were masked using a positive photoresist (the mask patterns are shown in Figure 4), leaving the open part of the ITO that must be etched. The substrates were then etched using an aqueous solution of $\mathrm{HCl} / \mathrm{HNO}_{3} / \mathrm{H}_{2} \mathrm{O}$ at a temperature of $60^{\circ} \mathrm{C}$ for 120 seconds, and then cleaned by ultrasonication in water, aceton and isopropanol for 15 minutes, respectively, before dried in $\mathrm{N}_{2}$.

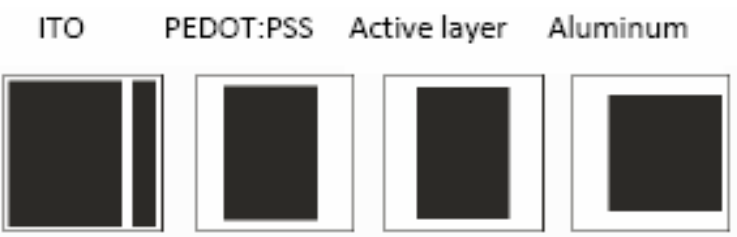

Figure 4. The mask patterns of ITO, PEDOT:PSS, active layer, and aluminum

Prior employed the active layer, the poly(3,4ethylene dioxythiophene) : poly(styrene sulphonate) (PEDOT:PSS) in $\mathrm{H}_{2} \mathrm{O}$ (Aldrich 655201) was spincoated onto the freshly prepared substrates at 2800 rpm for 30s using an adhesive tape mask. After removal of the mask, the substrates were dried in a vacuum oven at $120^{\circ} \mathrm{C}$ for 60 minutes. The devices then masked again and solution blends of MDMOPPV (Aldrich 546461) and PCBM (Aldrich 684457) $1: 1 \mathrm{wt} / \mathrm{wt}$ and 1:4 wt/wt in chorobenzene were spincoated on the top. The mask was removed, and the substrates were transferred to a sputtering where the aluminum to be coated.

For the cathode, a $134 \mathrm{~nm}$ thick film of aluminum was sputtered onto the active layer through a shadow mask to define an active device area of 2.6 $\mathrm{cm}^{2}$. The sputter parameter was $75 \mathrm{Watts}$ in dc power for 10 minutes. Some of the devices then annealed in a vacuum oven at $60^{\circ} \mathrm{C}$ for 60 minutes.

Glass slide in $20 \mathrm{~mm}$ x $20 \mathrm{~mm}$ dimensions were employed to match the sealing area of the back of the photovoltaic device. The sealants (Dyesol TPS 065093-50) were placed between the devices and the glass slides and cured in a vacuum oven at 
temperature $100^{\circ} \mathrm{C}$ for 10 minutes. The devices (as shown in Figure 5) were ready for electric characterization. The I-V characteristics for the devices were obtained using a solar simulator with a xenon lamp (AM 1.5 filtered). The incident light intensity was approximately $27 \mathrm{~mW} / \mathrm{cm}^{2}$, and the temperature was $25^{\circ} \mathrm{C}$. Electrical measurements were performed using a I-V Measurement from National Instrument. The surfaces of the active layers before and after annealing treatment were investigated using atomic force microscopy (AFM).

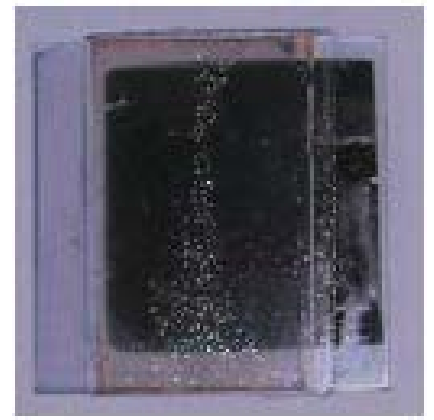

Figure 5. The polymer solar cell prototype.

\section{RESULT AND DISCUSSION}

Figure 6 shows the current density vs voltage (I-V) characteristics under a solar simulator with an intensity of $27 \mathrm{~mW} / \mathrm{cm}^{2}$. The electric characteristics are shown in Table 1 . The devices without annealing treatment (casting) show high performance with open circuit voltage $\left(\mathrm{V}_{\mathrm{OC}}\right)=0.347 \mathrm{~V}$, short circuit current $\left(\mathrm{I}_{\mathrm{SC}}\right)=0.064 \mathrm{~mA}$, fill factor $(\mathrm{FF})=0.280$, and $\mathrm{V}_{\mathrm{OC}}=$ $0.184 \mathrm{~V}, \mathrm{I}_{\mathrm{SC}}=0.072 \mathrm{~mA}, \mathrm{FF}=0.515$ for blend ratio of $1: 1$ and $1: 4$, respectively. The power conversion efficiency $(\eta)$ for these devices are similar, $\eta=0.01 \%$, and $\eta=0.01$. The devices with annealing treatment at $60^{\circ} \mathrm{C}$ for 60 minutes exhibit poorer performance than without annealing. The $\mathrm{V}_{\mathrm{OC}}, \mathrm{I}_{\mathrm{SC}}$, and $\mathrm{FF}$ are lower, resulting in $0.041 \mathrm{~V}, 0.065 \mathrm{~mA}, 0.293$ and $0.102 \mathrm{~V}$, $0.075 \mathrm{~mA}, 0.235$ for blend ratio of $1: 1$ and $1: 4$, respectively. The corresponding power conversion efficiencies are therefore, only $\eta=0.001 \%$, and $\eta=$ $0.003 \%$. The low in power conversion efficiency is mainly caused by a significant low in $\mathrm{V}_{\text {OC }}$. This result is in agreement with previous publications on the effects of thermal annealing of MDMO-PPV/PCBM polymer blends. They reported that a sudden drop in efficiency after annealing for only a few seconds at $130^{\circ} \mathrm{C}$ or a few minutes at $75^{\circ} \mathrm{C}$ and $80^{\circ} \mathrm{C}$ (Yang and
Loos, 2007; Padinger et al., 2003; Chirvase et al., 2004). The origin of this instability was degradation of the morphology resulted from the formation of large PCBM aggregates (Chirvase et al., 2004; Hoppe et al., 2004). The formation of PCBM aggregations can be seen at Figure 7.

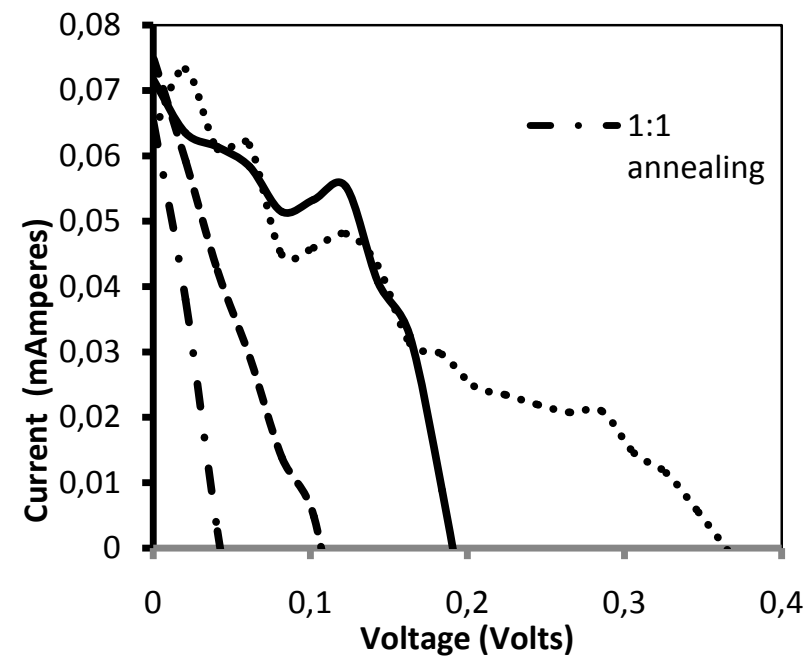

Figure 6. I-V characteristics of MDMO-PPV/PCBM polymer solar cells

As seen in Table 1, it was demonstrated that the power conversion efficiency for the devices with low concentration of PCBM (1:1 MDMO$\mathrm{PPV} / \mathrm{PCBM}$ ) is similar to the devices with high concentration of PCBM (1:4 MDMO-PPV/PCBM). However, the $\mathrm{V}_{\mathrm{OC}}$ of the devices of 1:1 MDMO$\mathrm{PPV} / \mathrm{PCBM}$ is higher compared to that of $1: 4$ MDMO-PPV/PCBM, while the FF and $\mathrm{I}_{\mathrm{sc}}$ are lower. This indicates that the higher PCBM ratio is strongly contributed to the degradation of the $\mathrm{V}_{\mathrm{OC}}$, but on the other hand, it also increases the FF and $\mathrm{I}_{\mathrm{SC}}$. Therefore, to increase the efficiency; it is necessary to optimize the ratio between MDMO-PPV and PCBM blends.

In general, the electrical characteristics of all the devices are not as expected, particularly in open circuit voltage, short circuit current and fill factor. The low in $\mathrm{V}_{\mathrm{OC}}$ and $\mathrm{I}_{\mathrm{SC}}$ may be caused by utilizing of sputtered $\mathrm{Al}$ as a cathode layer, where sputtering process can result in damage to organic solar cell absorber (active) layer as a result of the bombardment of highly energetic particles such as reflected argon ions or scattered electrons (Ahlswede et al., 2007).

Table 1. Electrical Characteristics of MDMO-PPV/PCBM polymer solar cells

\begin{tabular}{llcccc}
\hline No. & \multicolumn{1}{c}{ Characteristics } & $\begin{array}{c}1: 1 \\
\text { casting }\end{array}$ & $\begin{array}{c}1: 1 \\
\text { annealing }\end{array}$ & $\begin{array}{c}1: 4 \\
\text { casting }\end{array}$ & $\begin{array}{c}1: 4 \\
\text { annealing }\end{array}$ \\
\hline 1. & Open circuit voltage, $\mathrm{V}_{\mathrm{OC}}$ (Volt) & 0.347 & 0.041 & 0.184 & 0.102 \\
2. & Maximum voltage, $\mathrm{V}_{\mathrm{m}}$ (Volt) & 0.143 & 0.021 & 0.123 & 0.062 \\
3. & Short circuit current, I $\mathrm{I}_{\mathrm{SC}}$ (mAmpere) & 0.064 & 0.065 & 0.072 & 0.075 \\
4. & Maximum current, $\mathrm{I}_{\mathrm{m}}$ (mAmpere) & 0.043 & 0.038 & 0.055 & 0.029 \\
5. & Maximum power, $\mathrm{P}_{\mathrm{m}}$ (mWatt) & 0.006 & 0.001 & 0.007 & 0.002 \\
6. & Fill factor, FF & 0.280 & 0.2931 & 0.515 & 0.235 \\
7. & Efficiency, $\eta(\%)$ & 0.010 & 0.001 & 0.010 & 0.003 \\
\hline
\end{tabular}



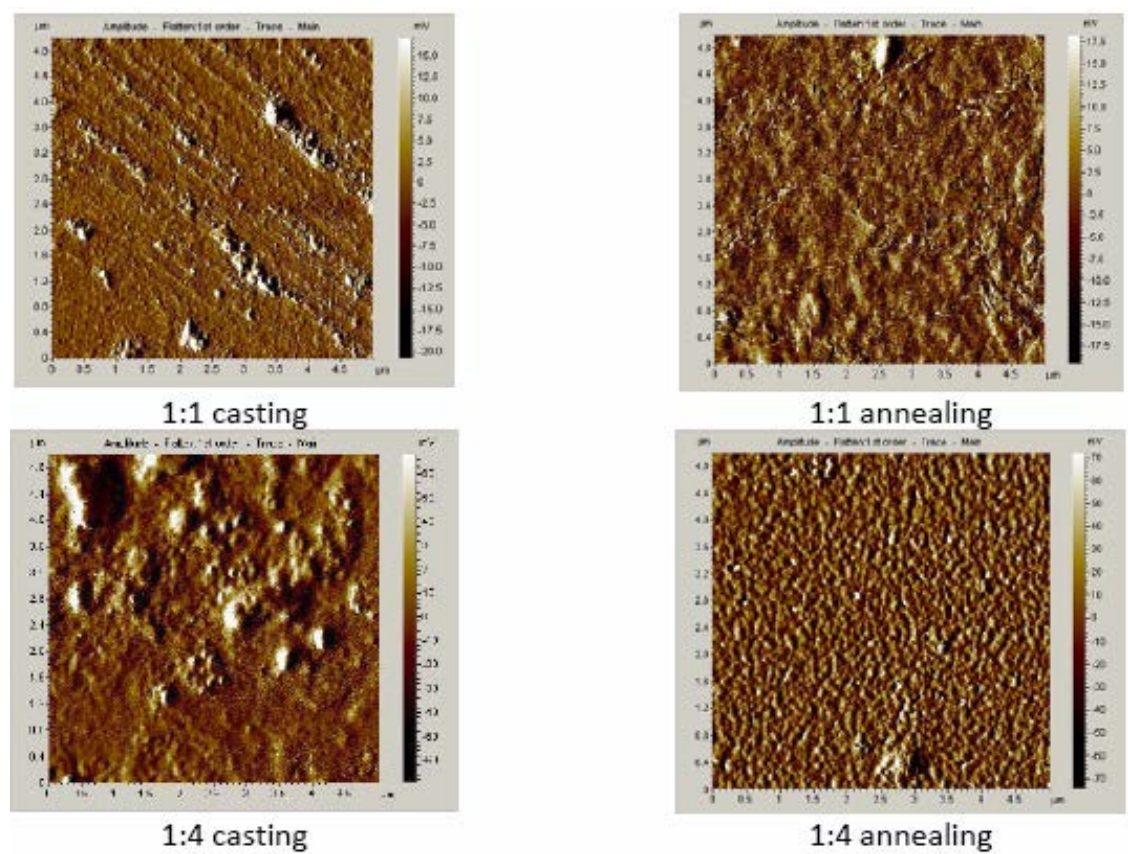

Figure 7. AFM images of MDMO-PPV/PCBM films in polymer solar cells

The low in fill factor implies high series resistance and low carrier mobility, which is caused by the effect of impurities, such as oxygen, which act as traps to the migrating excitons (Wallace et al., 2000). Another factors which also decrease the electrical characteristic are the larger active area and the temperature of sealing.

Atomic force microscopy (AFM) images of the MDMO-PPV/PCBM surface films before and after annealing treatment, are shown in Figure 7. It was shown in Figure 7 that the films without annealing treatment (casting) has a smoother surface than the films with annealing treatment. Annealing treatment forms a roughness surface with more regularly PCBM clusters, especially on the surface of 1:4 MDMOPPV/PCBM film. Annealing treatment also suppress the PCBM cluster. Annealing of the 1:4 MDMOPPV/PCBM film forms fine and homogeny PCBM cluster, corresponding to well intermixing system is observed. The donor/acceptor (D/A) (MDMO-PPV as a donor and PCBM as an acceptor) domains can be distinguished, so that interpenetrating D/A network became clearer and easily visible. This characteristic result in a large interfacial area which should enhance the efficient charge generation. However, the device based on the active layer of 1:4 MDMO-PPV/PCBM with annealing treatment results in poorer performance than without annealing treatment. It is caused by sputtering process for aluminum chatode as mentioned before. During the sputtering processes energetic particles such as reflected argon neutrons, high energy $\gamma$-electron, and charged ions are injected on the surface of a thin electron injection layer or an organic layer and transfer their high energies the bombardment energetic particle usually causes the formation of defect and local trap sites, resulting in the structural and electrical deterioration of organic films.
Moreover, the bombardment also increases the surface temperature which leads to the degradation of the characteristics of organic layer (Kim, 2005).

\section{CONCLUSIONS}

Polymer solar cells based on blends of [poly(2methoxy-5-(3,7-dimethyloctyloxy)-para phenylene vinylene)] (MDMO-PPV) and [6,6 phenyl C61butyric acid methyl ester] (PCBM) have been prepared on a glass substrate. The best performance was obtained from the device with a blend ratio of $1: 1$ MDMO-PPV/PCBM without annealing treatment. The typical power efficiency was $0.01 \%$ with open circuit voltage of $0.347 \mathrm{~V}$, short circuit current of $0.064 \mathrm{~mA}$, and maximum power of $0.006 \mathrm{~mW}$.

\section{ACKNOWLEDGEMENT}

This work is supported by DIPA Programme of PPET-LIPI 2011-2013.

\section{REFERENCES}

Ahlswede, E., Hanisch, J., and Powalla, M., (2007), Influence of cathode sputter deposition on organic solar cells, Applied Physics Letters, 90, pp. 063513, pp. 1-3.

Brabec, C.J., (2004), Organic photovoltaics: technology and market, Solar Energy Materials \& Solar Cells, 83, pp. 273-292.

Chen, L.M., Hong, Z., Li, G., and Yang, Y., (2009), Recent Progress in Polymer Solar Cells: Manipulation olymer: Fullerene Morphology and the Formation of Efficient Inverted Polymer Solar Cells, Advanced Materials, 21, pp. 1434-1449. 
Chirvase, D., Parisi, J., Hummelen, J.C., and Dyakonov, V., (2004), Influence of nanomorphology on the photovoltaic action of polymer-fullerene composites, Nanotechnology, 15, pp. 13-17.

Hoppe, H., Niggemann, M., Winder, C., Kraut, J., Hiesgen, R., Hinsch, A., Meissner, D., and Sariciftci, N.S., (2004), Nanoscale Morphology of Conjugated Polymer/Fullerene-Based Bulk-Heterojunction Solar Cells, Advanced Functional Materials, 14, pp. 10051011.

Kim, H.K., (2005), Plasma damage-free sputtering of indium tin oxide cathode layers for top-emitting organic light-emitting diodes, Applied Physics Letters, 86 (18), pp. 183503, pp.1-3.

Mozer, A.J. and Sariciftci, N.S., (2006), Conjugated polymer photovoltaic devices and materials, Comptes Rendus Chimie, 9, pp. 568-577.
Padinger, F., Rittberger, R.S., and Sariciftci, N.S., (2003), Effects of Postproduction Treatment on Plastic Solar Cells, Advanced Functional Materials, 13, pp. 85-88.

Veenstra, S.C., Verhees, W.J.H., Kroon, J.M., Koetse, M.M., Sweelssen, J., Bastiaansen, J.J.A.M., Schoo, H.F.M., Yang, X., Alexeev, A., Loos, J., Schubert, U.S., and Wienk. M.M., (2004), Photovoltaic properties of a Conjugated Polymer Blend of MDMOPPV and PCNEPV, Chemistry of Materials, 16, pp. 2503-2508.

Wallace, G.G., Dastoor, P.C., Officer, D.L., and Too, C.O., (2000), Conjugated polymers: New materials for photovoltaics, Chemical Innovation, 30 (1), pp. 14-22.

Yang, X. and Loos, J., (2007), Toward HighPerformance Polymer Solar Cells: The Importance of Morphology Control, Macromolecules, 40 (5), pp. 1353-1362. 